\title{
PTSD Symptoms in Afghan Refugees in the UK
}

\author{
Mariwan Husni (Corresponding author) \\ Northern Ontario School of Medicine (NOSM) Faculty, Consultant Psychiatrist, Central and \\ Northwest London Foundation NHS Trust \\ Northwick Park Hospital, Harrow, Greater London, HA1 3UJ, UK \\ Tel: 44-020-8869-1571_E-mail: mariwan.husni@gmail.com
}

\section{Ghafoor Rahim}

Specialty Doctor, Central and Northwest London Foundation NHS Trust

Northwick Park Hospital, Harrow, Greater London, HA1 3UJ, UK

Tel: 44-020-8869-2308Ｅ-mail: agrahim@nhs.net

\section{Zack Cernovsky}

Professor, Department of Psychiatry, University of Western Ontario

London, Ontario, Canada

Tel: 1-519-685-8500Ｅ-mail: zcernovs@uwo.ca

Received: October 23, 2014 Accepted: November 17, $2014 \quad$ Published: March 18, 2015

doi:10.5296/ijssr.v3i1.7268ＵRL: http://dx.doi.org/10.5296/ijssr.v3i1.7268

\begin{abstract}
Objective: To evaluate anamnestic and sociodemographic correlates of PTSD symptoms in refugees from Afghanistan.

Method: Fifty Afghan refugees in the UK (mean age 37.4 years, $\mathrm{SD}=12.1 ; 33$ men, 17 women) underwent SCID interview for PTSD, administered in their native language (Pashtun or Dari).

Results: Eighteen (36.0\%) reported being tortured while in Afghanistan. More than half $(54.0 \%)$ of these refugees met criteria for PTSD. While the diagnosis was not significantly
\end{abstract}


related to age, gender, education, and history of torture, those free of PTSD rated their present occupation in UK as more satisfactory $(\mathrm{r}=.28, \mathrm{p}=.048)$.

Almost a half (46.0\%) of these refugees reported nightmares about the circumstances of their escape from Afghanistan.

Conclusions: Although PTSD symptoms were noted in more than a half of our sample, they were related neither to history of torture nor to sociodemographic variables (age, gender, education).

Keywords: PTSD, refugees, Afghanistan

\section{Introduction}

Post Traumatic Stress Disorder (PTSD) is a frequent but usually underdiagnosed phenomenon among refugees from war torn countries such as Afghanistan (Malekzai, 1996).

Afghan refugees comprise one of the largest refugee populations in the world numbering more than 6 million. The vast majority of Afghan refugees were subjected to psychological trauma in their country of origin and now struggle to cope with the process of assimilation in the host country, i.e. with economic and occupational difficulties, limitations in health-care access, cross-cultural family and children's issues, and immigration issues (Omeri, 2006). Studies have shown that the mental health status of Afghans and their traumatic experiences during decades of conflict has resulted in poorer social functioning and higher prevalence of symptoms of anxiety, and PTSD (Cardozo, 2004). The interplay of multilevel stressors contributes to a higher vulnerability for the development of PTSD (Catani, 2009).

The prevalence of psychiatric disorders among adult Afghan refugees living in Europe and America is higher than among the general population (Gernaat, 2002). A significant proportion of adolescent and young adult Afghan refugees in the community suffer from severe but undiagnosed psychiatric disorders (Mghir, 1995). PTSD symptoms are notoriously prevalent but usually remain undocumented and their socio-demographic context remains largely unexplored. The validity of PTSD symptoms in the cultural context of adults in Afghanistan has been supported by studies with this group and the shared common variance has been correlated with exposure to traumatic stress (Miller 2009).

The goal of the present study was to evaluate anamnestic and sociodemographic correlates of PTSD symptoms in refugees from Afghanistan.

\section{Method}

A community sample of fifty refugees from Afghanistan in the UK (age 18 to 60 years, with the average at $37.4, \mathrm{SD}=12.1 ; 33$ men, 17 women) participated in the study.

Some left Afghanistan due to the invasion by Soviet forces in 1979, or during the subsequent ethnic tensions and violence associated with the Taliban. The time since escape from Afghanistan (measured in years) ranged from 2 to 25 years, with the average at 11.9 years $(\mathrm{SD}=7.6)$. Some of them were children when they left their homeland, escaping with family or relatives: the age at the time of escape ranged from 2 to 50 years, with the average age of 
25.6 ( $\mathrm{SD}=11.1)$. Many at first lived in neighbouring countries (19 in Pakistan, 6 in India, 5 in Russia, and one in Uzbekistan) for, on average 4.9 years $(\mathrm{SD}=5.2)$ before commencing their journey towards UK.

At the time of the study, all refugees had lived in the UK for at least one year and all but 2 lived there for at least 2 years. On average, they have lived in the UK for 8.8 years $(\mathrm{SD}=7.5)$.

Their education was usually only very brief, disrupted by war or poverty, with an average of only 3.7 years $(\mathrm{SD}=2.4)$ of formal schooling. In the $\mathrm{UK}$, at the time of the interview, $23(46 \%)$ were unemployed, 18 (36\%) were self-employed, one was a labourer, one was a mechanic, and the rest were employed in white collar professions. Sixteen (32\%) were presently studying, trying to upgrade their educational level.

All participants underwent extensive structured interviews conducted in their native language (Pashtun or Dari) by one of the authors (Dr. Rahim), who is of the same cultural background. All of them were administered Structured Clinical Interview for DSM-IV (SCID) for PTSD (First, 1996). Furthermore, brief ratings were collected on items adopted from Cernovsky's Assimilation Scale (Cernovsky, 1990; Husni, 2002) to measure their satisfaction with life in the UK with respect to their present occupation, personal safety, available health care, food, and local entertainment (UK style or Afghan style): each of these dimensions of assimilation was separately rated via a 3 point scale with $1=$ not satisfied, $2=$ somewhat satisfied, $3=$ definitely satisfied.

All refugees were asked if they have nightmares about the circumstances of their escape from Afghanistan and if they had been subjected to torture.

The procedures met the requirements of the local research ethics committee and all participants provided their informed consent.

\section{Results}

Frequency of torture and of PTSD: Slightly more than a third $(36.0 \%)$ of the refugees reported that they were, at some point, seized and tortured while in Afghanistan. When only those older than 15 years $(\mathrm{N}=41)$, at the time of escape from Afghanistan, are included, then the proportion of those who experienced torture increases to $41.5 \%$.

Almost half $(46.0 \%)$ of the refugees reported nightmares about the circumstances of their escape from Afghanistan. When only those older than 15 years, at the time of escape from Afghanistan, are included, then the proportion of those with escape nightmares increases to $51.2 \%$.

The translation and explanation of the PTSD items to the refugees was complicated by sociocultural barriers. For example, even after the item ("Intense psychological distress at exposure to internal or external cues") is meticulously translated into Pushtun or Dari, it still remains unclear whether some refugees understood this correctly or would admit to psychological symptoms as many spent their formative years in a primarily agricultural society, devastated by armed conflict, and deprived of adequate schooling. Our conservative diagnosis probably underestimates the PTSD frequency, with possibility of false negatives. In 
this unusual context, $54.0 \%$ (27 of 50 ) of the refugees were classified as suffering from PTSD.

Correlates of PTSD: The diagnosis was unrelated to age, gender, and education (point biserial and phi coefficients, $\mathrm{p}>.05$, 2-tailed). Those who reported nightmares about the circumstances of their escape from Afghanistan were also more frequently among those diagnosed as suffering from PTSD ( $\mathrm{phi}=.45, \mathrm{p}=.001$ ). There was a similar but not statistically significant trend with respect to history of being tortured ( $\mathrm{phi}=.27, \mathrm{p}=.054)$ : those tortured were somewhat more likely to be diagnosed with PTSD.

Those more satisfied with their present occupation in the UK and also those more satisfied with the UK style entertainment or also with the Afghan style entertainment as available within UK were less frequently classified as suffering from PTSD (correlation coefficients of $.28, p=.048$ for occupation, of $.34, p=.016$ for local entertainment, and of $.38, p=.007$ for Afghan style entertainment).

The proportions are similar in those older than 15 years at the time of escape and in their younger counterparts. The proportions of those meeting each of the individual criteria for PTSD are listed in Table 1:

Table 1. PTSD associated symptoms in those younger than 15 years while escaping Afghanistan and in their older counterparts

\begin{tabular}{|c|c|c|}
\hline Symptoms Present & $\begin{array}{l}\text { PTSD } \\
\text { In those } \leq 15 \text { at } \\
\text { the time of escape from } \\
\text { Afghanistan }\end{array}$ & $\begin{array}{l}\text { PTSD } \\
\text { In those }>15 \text { at } \\
\text { the time of escape from } \\
\text { Afghanistan }\end{array}$ \\
\hline Exposure to Traumatic stress & $38.3 \%$ & $38.5 \%$ \\
\hline $\begin{array}{l}\text { Experience of intense fear, helplessness, or } \\
\text { horror }\end{array}$ & $32.0 \%$ & $34.1 \%$ \\
\hline $\begin{array}{l}\text { Distressing recollections or re-living of the } \\
\text { event }\end{array}$ & $28.0 \%$ & $29.3 \%$ \\
\hline Distressing dreams of the event & $28.0 \%$ & $29.3 \%$ \\
\hline $\begin{array}{l}\text { Acting or feeling as if re-experiencing the } \\
\text { traumatic event }\end{array}$ & $24.0 \%$ & $26.8 \%$ \\
\hline Difficulties falling asleep or staying asleep & $26.0 \%$ & $29.3 \%$ \\
\hline Irritability / outbursts of anger & $34.0 \%$ & $36.6 \%$ \\
\hline Hypervigilance, poor frustration tolerance & $25.5 \%$ & $28.2 \%$ \\
\hline $\begin{array}{l}\text { Avoiding stimuli associated with the trauma or } \\
\text { related feelings }\end{array}$ & $26.0 \%$ & $29.3 \%$ \\
\hline $\begin{array}{l}\text { Inability to recall important aspects of the } \\
\text { trauma }\end{array}$ & $34.0 \%$ & $34.1 \%$ \\
\hline Detachment or estrangement from others & $16.0 \%$ & $19.5 \%$ \\
\hline $\begin{array}{l}\text { Loss of interest or participation in significant } \\
\text { activities }\end{array}$ & $28.6 \%$ & $32.5 \%$ \\
\hline Poor appetite & $21.3 \%$ & $20.5 \%$ \\
\hline
\end{tabular}




\section{Discussion}

The high frequency of PTSD among the Afghan refugees in our sample (54\%) exceeds not only the rates of 5\% to $10 \%$ found in the recent comorbidity survey of Americans (Kessler, 1996), but also those recently reported by De Jong et al (2001) for various other conflict-afflicted settings including Cambodia (28\%), Ethiopia (16\%), Algeria (37\%), and Gaza (18\%). When evaluated statistically, PTSD rates in our sample of Afghan refugees in the UK are significantly higher than those found in Algerians (chi square $=5.42, \mathrm{df}=1, \mathrm{p}$ $<.02$ ), Cambodians (chi square $=14.38, \mathrm{df}=1, \mathrm{p}<.001$ ), Ethiopians ( chi square $=48.74, \mathrm{df}=1$, $\mathrm{p}<.001$ ), and in residents of Gaza (chi square $=36.91$, $\mathrm{df}=1, \mathrm{p}<.001$ ). It must be noted, however, that these latter 4 groups may be distinctly different from those who decided to leave their respective countries. It is possible that refugees usually are a more traumatized group than their compatriots who stay in the native country. Unfortunately, we have no data on frequency of PTSD in the current residents of Afghanistan.

The failure of the history of torture in our sample of 50 Afghans to correlate with PTSD diagnosis contrasts with the data by De Jong's team who found the relationship to be significant in all settings except for Cambodia. It should be noted, however, that the underlying trend in our Afghan sample was in the expected direction.

Nightmares in which refugees are again in their home country, wishing to or attempting to escape were reported by $46 \%$ of the refuges in our Afghan sample. The proportion of these dreams is similar to the one found by Cernovsky (1988) in Czechoslovak refugees from communist dictatorship (56.0\% reported the escape nightmares) but is far lower than in refugees from Kurdistan at the time of Saddam Hussein's genocide campaign (88.9\% reported escape nightmares) (Husni, 2001).

The weaknesses of this study include small sample size and perhaps also the conceptual obstacles some of the refugees faced with respect to definitions of some of the PTSD symptoms. A restricted scope of related vocabulary, as in some of our refugees, could at least partly impede their ability to communicate about more subtle aspects of their PTSD symptoms.

The main contribution of this study lies in providing preliminary data in this neglected area of cross-cultural psychiatry. Further research on larger samples of refugees from countries afflicted by armed conflict or persecution is needed to help to develop more adequate mental health support and less arduous avenues of successful adaptation of these new immigrants in the host country.

\section{Conclusions}

The rate of PTSD (54\%) in Afghan refugees exceeds rates found for those who stayed in other war afflicted countries (15.5 to 37.4\%). In our sample, PTSD symptoms were not significantly related to history of torture and to sociodemographic variables (age, gender, education). Refugees without PTSD symptoms rated life in the host country as more satisfactory. 
Almost half $(46 \%)$ of the refugees reported nightmares about the circumstances of their escape from Afghanistan.

\section{Limitations of the Study}

- Small sample size.

- Socio-educational or cultural barriers to communication about subtle aspects of PTSD symptoms with some refugees may lead to false negatives.

\section{References}

Cardozo, B. L., Bilukha, O. O., Gotway Crawford, C. A., Shaikh, I., Wolfe, M. I., Gerber, M. L., \& Anderson, M. (2004). Mental Health, Social Functioning, and Disability in Postwar Afghanistan. JAMA, 292(5), 575-584. http://dx.doi.org/10.1001/jama.292.5.575

Catani, C., Schaue, E., Elbert, T., Missmah, I., Bette, J. P., \& Neuner, F. (2009). War trauma, child labor, and family violence: Life adversities and PTSD in a sample of school children in Kabul. Journal of Traumatic Stress, 22(3), 163-171. http://dx.doi.org/10.1002/jts.20415

Cernovsky, Z. Z. (1988). Refugees' repetitive nightmares. J Clin Psychol., 44(5), 702-7. http://dx.doi.org/10.1002/1097-4679(198809)44:5<702::aid-jclp2270440506>3.0.co;2-d

Cernovsky, Z. Z. (1990). Escape stress, sleep disorders, and assimilation level of refugees. Social Behavior and Personality, 18, 287-298. http://dx.doi.org/10.2224/sbp.1990.18.2.287

De Jong, J., Komproe, T. V. M., Ivan, H., Von Ommeren, M., El Masri, M., Araya, M., ... Somasundaram, D. J. (2001). Lifetime events and Posttraumatic Stress Disorder in 4 postconflict settings. JAMA, 286(5), 555-562. http://dx.doi.org/10.1001/jama.286.5.555

First, M. B., Spitzer, R. L., Gibbon, M., \& Williams, J. B. (1996). Structured Clinical Interview for the DSM-IV Axis I Disorders. Arlington, VA, American Psychiatric Publishing, Inc.

Gernaat, H. B., Malwand, A. D., Laban, C. J., Komproe, I., De Jong, J. T. (2002). Many psychiatric disorders in Afghan refugees with residential status in Drenthe, especially depressive disorder and post-traumatic stress disorder. Ned Tijdschr Geneeskd, 146(24). 1127-31.

Husni, M., Cernovsky Z. Z., Koye, N., \& Haggarty, J. (2001). Nightmares of refugees from $\begin{array}{lllll}\text { Kurdistan. } & J & \text { Nerv } & \text { Ment } & \text { Disease, }\end{array}$ http://dx.doi.org/10.1097/00005053-200108000-00010

Husni, M., Cernovsky, Z., Koye, N., \& Haggarty, J. (2002). Sociodemographic correlates of assimilation of refugees from Kurdistan. Psychological Reports, 90(1), 67-70. http://dx.doi.org/10.2466/pr0.90.1.67-70

Kessler, R.C., Sonnega, A., Bromet, E., Hughes, M., \& Nelson, C. B. (1996). Posttraumatic Stress Disorder in the National Comorbidity Survey. Archives of General Psychiatry, 52, 1048-1060. http://dx.doi.org/10.1001/archpsyc.1995.03950240066012 


\section{Macrothink}

Malekzai, A. S., Niazi, J. M., Paige, S. R., Hendricks, S. E., Fitzpatrick, D., Leuschen, M. P., \& Millimet, C. R. (1996). Modification of CAPS-1 for diagnosis of PTSD in Afghan refugees. J Trauma Stress, 9(4), 891-8. http://dx.doi.org/10.1007/bf02104111

Mghir, R., Freed, W., Raskin, A., \& Katon, W. (1995). Depression and posttraumatic stress disorder among a community sample of adolescent and young adult Afghan refugees. J Nerv Ment Dis., 183(1), 24-30. http://dx.doi.org/10.1097/00005053-199501000-00005

Miller, K. E., Omidian, P., Kulkarni, M., Yaqubi, A., Daudzai, H., \& Rasmussen, A. (2009). The Validity and Clinical Utility of Post-traumatic Stress Disorder in Afghanistan. Transcultural Psychiatry, 46(2), 219-237. http://dx.doi.org/10.1177/1363461509105813

Omeri, A., Lennings, C., Raymond, L. (2006). Beyond asylum: implications for nursing and health care delivery for Afghan refugees in Australia. J Transcult Nurs., 17(1), 30-9. http://dx.doi.org/10.1177/1043659605281973

\section{Copyright Disclaimer}

Copyright for this article is retained by the author(s), with first publication rights granted to the journal.

This is an open-access article distributed under the terms and conditions of the Creative Commons Attribution license (http://creativecommons.org/licenses/by/3.0/). 